\title{
Lead Toxicity and the Hypothalamic-Pituitary-Testicular Axis
}

\author{
Nadia AIT HAMADOUCHE, Sadi NESRINE, Aoues ABDELKEDER \\ University Oran, Laboratory of Experimental Biotoxicology, Biodepollution and Phytoremediation \\ Department of Biology, Algeria; naithamadouche@live.fr
}

\begin{abstract}
Environmental exposure to toxic levels of lead $(\mathrm{Pb})$ occurs in a number of industries with potential adverse effects on the reproductive capacity of exposed men. Clinical and animal studies indicate that abnormalities of spermatogenesis result from toxic lead exposure, but eventual histopathologic alterations involved have not been identified. To explore putative abnormalities in the reproductive gonadotropic axis following lead intoxication, experimental animals when exposed to low levels of lead, 65 days old animals were treated with distilled water containing $0,0 \mathrm{mg}$ (control), $10 \mathrm{mglead}(\mathrm{Pb}) / \mathrm{Kg}$ /day and $15 \mathrm{mg}$ lead $(\mathrm{Pb}) / \mathrm{Kg} /$ day intraperitoneally for $20 \mathrm{days}$. At the end of treatment, the animals were sacrificed and the blood collected for luteinizing hormone (LH) and testosterone assays. The testis was processed for histological analysis. The results showed a high serum concentration of LH and testosterone in lead-treated animals compared to controls. Histological examination of testis showed deformities in testicular morphology of lead intoxicated animals with gross damage within the somniferous tubules. A strong correlation was established between LH and testosterone suggestingan alteration in the endocrine components of the gonadotropic axis. Histological examination of pituitary gland showed some degenerative changes in endocrine cells of lead group. Changes in - $\mathrm{LH}$ and testosterone levels suggest that $\mathrm{Pb}$ exposure during the critical time of sexual differentiation induces reproductive axis abnormalities in adulthood. In conclusion, lead has a gonadotoxic effect by decreasing $\mathrm{LH}$ and testosterone levels and damaging the testis seminiferous tubules. Catalase activity was significantly reduced in the lead group following 65 days of exposure which possibly indicates that lead might had other mechanisms of action, such as increasing oxidative damage.
\end{abstract}

Keywords: hypothalamic-pituitary axis, lead, sex hormone

\section{Introduction}

Lead is considered as one of the major environmental pollutants. It may have different origins such as contaminated food, unsanitary preservation of food, lead hydrous piping, industrial pollution, road traffic and drinking water (López-Carrillo et al., 1996). Exposure to lead could damage nervous systems by provoking neuropsychological disturbances (Hogstedt et al., 1983), motor and sensory conduction velocities (Seppäläinen et al., 1983), and alter the heme synthesis (Piomelli, 1981). It can also induce acute nephrotoxicity (Goyer, 1989), cause disturbances of the reproductive system (Apostoli et al., 1998; Goyer, 1990) and increase blood pressure (Hertz-Picciotto and Croft, 1993; Schwartz, 1995). Some other studies have shown that it can increase the risks of lung cancer (Anttila et al., 1995). In animals, several experimental studies have reported impairment of the spermatogenesis (Der et al., 1976; Gorbel et al., 2002) but the mechanisms implied in the pathogenesis are not yet completely understood. Indeed, some works suggested a direct toxic action on the hypothalamic-pituitary axis, such as the study of (Stumpf et al., 1980) which mentioned a fall in the number of spermatozoa in the testis; In addition, other studies showed that the toxicity of lead appears primarily on the interstitial cells by the inhibition of enzymes synthesis implied in the steroidogenesis and of the hormonal receivers (Thoreux-Manlay et al., 1995; Wiebe et al., 1983). It has been demonstrated that chronic lead exposure, for 8 weeks, resulted in an appreciable accumulation of lead in different rat regions (Sandhir et al., 1994). This increase was accompanied by an increase in lipid peroxidation and a concomitant decrease in the activities of catalase and other antioxidant enzymes (Sandhir et al., 1994). In other studies, the activity of catalase in erythrocytes from workers occupationally exposed to lead was also significantly lower than that of control subjects (Cardona and Lessler, 1974; Sugawara et al., 1991).Therefore; it seems that chronic lead administration could reduce catalase activity in different organisms and tissues. The present work was aimed to investigate eventual action of lead on the pituitary and testicular components of the gonadotropic axis underlying alterations in reproductive function.

\section{Materials and methods}

\section{Animals}

Sixty-five days old animals were used for this study. Rats were housed in temperature controlled rooms $\left(25^{\circ} \mathrm{C}\right)$ with constant humidity (40-70\%) and 12/12 h light/ dark cycle prior to use in experimental protocols. All the procedure performed on animals were approved and conducted 
2

in accordance with the National Institute of health Guide (Reg. No. 488/160/1999/CPCSEA).

\section{Experimental design}

Three groups of rats were constituted (groups A, B, and $C, n=10)$. Control group $(A)$ were drinking distilled water. The experimental groups received daily $10 \mathrm{mg} / \mathrm{kg}$, group (B) and $15 \mathrm{mg} / \mathrm{kg}$ for group (C) to the end of the experimental design by intraperitoneal injections of lead acetate for 20 days.

At the end of the experimental design, the animals were sacrificed; the brains were removed immediately by opening the cranial cavity. During the course of the treatment, body weight of animals was recorded every 2 days.

\section{Determination of testosterone and LH serum levels}

Blood was collected from abdominal vein of all anesthetized rats after scarification. Serum was separated for assessment using (ABOTT) kits.

\section{Histological procedure}

Specimens from testicular tissues and pituitary were fixed in $10 \%$ neutral buffer formalin, dehydrated in ascending grades of ethanol alcohols, cleared in xylol, casted, blocked, cut at 2-5 $\mu \mathrm{m}$ thickness and stained with hematoxylin-eosin for microscopic examination (Bancroft et al., 1996).

\section{Lead acetate concentration}

Brain lead levels were measured in rats treated with lead acetate $(10 \mathrm{mg} / \mathrm{kg}$ and $15 \mathrm{mg} / \mathrm{kg})$. The brain collected at 20 days following this treatment. Digestion of dry brain samples was performed in a medium with nitric acid and 30\% hydrogen peroxide (Krachler et al., 1996). The lead acetate content in brain homogenates was measured by atomic absorption spectrophotometry (Perkin Elmer 1100 B) (Chakraborty et al., 1996).

\section{Catalase activity determination}

The whole brain was homogenized in a phosphate buffer $(50 \mathrm{mmol} / \mathrm{I} ; \mathrm{pH} 7.0)$ with digitonin (0.01\%). Brain homogenates were centrifugated at $10,000 \mathrm{rpm}$ for $10 \mathrm{~min}$ in an Eppendorf microcentrifuge. Supernatant aliquots were used to determined brain catalase levels. Catalase activity was assayed spectrophotometrically in the supernatants by measuring the decrease in absorbance of $\mathrm{H}_{2} \mathrm{O}_{2}$ at $240 \mathrm{~nm}$ (Aebi, 1984). Protein levels were determinated from supernatants (Bradford, 1976).

\section{Statistical analysis}

The results obtained from control and lead-poisoned animals are expressed as means \pm SEM. Statistical significance was determined by using Student's unpaired t-test. A $p$ value $<0.05$ was considered significant.

\section{Results}

\section{Body and brain weights}

Administration of lead acetate showed a significant decrease $(p<0.05)$ in body weight of treated rats. The decrease is $28.57 \%$ and $38.09 \%$ in rats treated at $10 \mathrm{mg} / \mathrm{kg}$ and $15 \mathrm{mg} / \mathrm{kg}$ respectively when compared with control. Brain weight also decrease significantly $(p<0.05)$ in treated groups; the decrease was $14.20 \%$ and $26.70 \%$ in rats treated at $10 \mathrm{mg} / \mathrm{kg}$ and $15 \mathrm{mg} / \mathrm{kg}$ respectively (Tab. 1).

Tab. 1. Effect of lead acetate on body, brain weights

\begin{tabular}{cccc}
\hline $\begin{array}{c}\text { Parameters/ } \\
\text { group }\end{array}$ & $\begin{array}{c}\text { Control } \\
(\mathrm{g})\end{array}$ & $10 \mathrm{mg} / \mathrm{kg}(\mathrm{g})$ & $15 \mathrm{mg} / \mathrm{kg}(\mathrm{g})$ \\
\hline Body weight & $210 \pm 2.88$ & $145 \pm 1.60^{*}(-28.57)$ & $130 \pm 1.98^{* *}(-38.09)$ \\
Brain weight & 1.76 & $1.51^{*}(-14.20)$ & $1.29^{* *}(-26.70)$ \\
\hline Values in brackets are \% decrease $(-) .{ }^{*} p<0.05 ;{ }^{* *} p<0.01$ &
\end{tabular}

\section{Elemental analysis}

The results of Student's t-test on lead residues in rat brain treated 20 days with $10 \mathrm{mg} / \mathrm{kg}$ and $15 \mathrm{mg} / \mathrm{kg}$ of lead acetate revealed that the group treated with $15 \mathrm{mg} /$ $\mathrm{kg}$ of lead acetate had significantly higher concentration of lead in their brains than the group treated with $10 \mathrm{mg} / \mathrm{kg}$ $(p<0.01)$. The mean \pm SEM for the lead-treated group at $15 \mathrm{mg} / \mathrm{kg}$ was $2.95 \pm 0.39 \mu \mathrm{g}$ of lead $/ \mathrm{g}$ of brain, and for lead at $10 \mathrm{mg} / \mathrm{kg}$ group, it was $0.94 \pm 0.21 \mu \mathrm{g}$ of lead/g of brain compared with the control (Fig. 1).

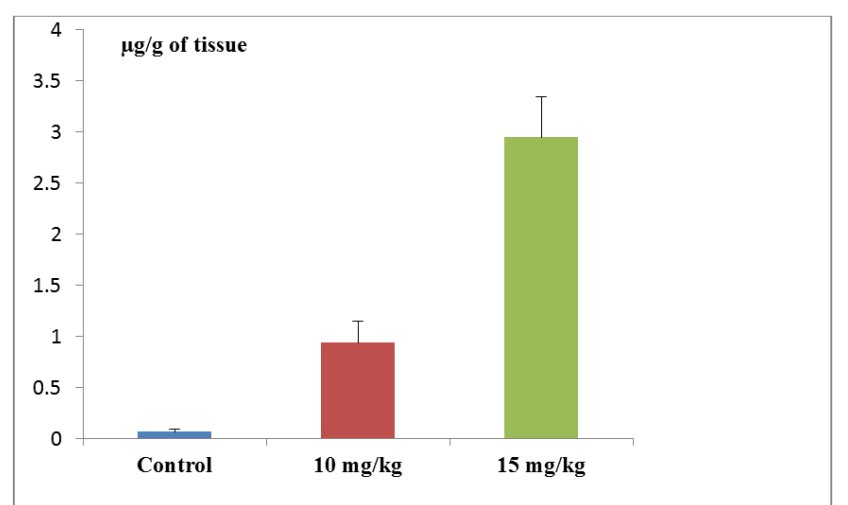

Fig. 1. Effect of lead acetate on lead concentration in rat brain. Values are mean \pm SD. ${ }^{*} p<0.05 ; p<0.01$

\section{Catalase activity}

The catalase activity comparisons revealed a significant decrease in brain catalase activity in animals treated with lead acetate during 20 days. The decrease is $39.04 \%$ and $45.9 \%$ in rat treated at $10 \mathrm{mg} / \mathrm{kg}$ and $15 \mathrm{mg} / \mathrm{kg}$ respectively when compared with control $(p<0.01)$ (Fig. 2).

\section{Hormonal parameters}

At the end of the 20-day treatment period, neither the plasma LH nor testosterone was found to be different from those of the control animals (Tab. 2). However, after 20 days of intoxication, the two hormones under- 


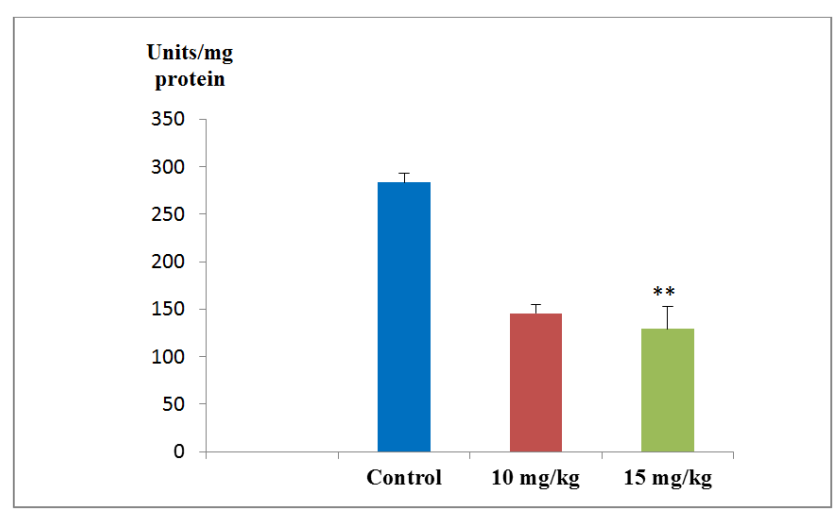

Fig. 2. Effect of lead acetate on catalase activity in brain rats. Values are mean $\pm \mathrm{SD} .{ }^{*} p<0.05 ;{ }^{* *} p<0.01$

went a significant animals treated at $15 \mathrm{mg} / \mathrm{kg}$ and $10 \mathrm{mg} /$ $\mathrm{kg}$ (respectively $2.70 \pm 0.49 ; 3.58 \pm 0.45$ vs $4.98 \pm 0.62 \mathrm{ng}$ / $\mathrm{ml}, p<0.01 ; 2.18 \pm 0.58 ; 4.38 \pm 0.40$ vs $6.82 \pm 0.73 \mathrm{ng} / \mathrm{ml}$, $p<0.01)$.

Tab. 2. Plasma LH and testosterone after 20 days of intraperitoneally exposure to lead acetate

\begin{tabular}{ccc}
\hline Groups & $\mathrm{LH}(\mathrm{ng} / \mathrm{ml})$ & Testosterone $(\mathrm{ng} / \mathrm{ml})$ \\
\hline Control & $4.98 \pm 0.62$ & $6.82 \pm 0.73$ \\
$10 \mathrm{mg} / \mathrm{kg}$ & $3.58 \pm 0.45^{*}$ & $4.38 \pm 0.40^{*}$ \\
$15 \mathrm{mg} / \mathrm{kg}$ & $2.7 \pm 0.49^{* *}$ & $2.18 \pm 0.58^{* *}$ \\
\hline
\end{tabular}

Data are means \pm SD. NS: significant difference ${ }^{* *} p<0.01 ;{ }^{*} p<0.05$

\section{Histopathologic changes of testis}

Compared with the control group (Fig. 3A), there were significant histopathological changes in $\mathrm{Pb}$-treated group. The main pathological changes induced atrophication of seminiferous tubules, the number of Leydig cells appeared to be lowered in the interstitium, and parts of Sertoli cells and Leydig cells showed shrunken cells with pyknotic nucleus with evidence of destruction (Fig. 3B), these histopatological changes are less marked in rats $\mathrm{Pb}$ treated at $10 \mathrm{mg} / \mathrm{kg}$ (Fig. 3C).

\section{Histopathologic changes in pituitary gland}

The fact that the testis is activated by a gonadotropic hormones principle had well been demonstrated in a number of ways. If a particular cell type in the pituitary is responsible for secretion of the gonadotropic hormone. Reference to Fig. $4 \mathrm{~A}$ will reveal a normal pituitary gland with uniform polygonal cells with round nuclei and clear cytoplasm. However, in $\mathrm{Pb}$-treated group at $10 \mathrm{mg} / \mathrm{kg}$ showed some degenerative changes in endocrine cells (Fig. 4B). The cells outlines tended to be indistinct, the cytoplasm stained less uniformly and cells had distorted, seemingly pyknotic. In $\mathrm{Pb}$ treated group at $15 \mathrm{mg} / \mathrm{kg}$ showed more exaggerated features, hypertrophy of endocrine cells and glial cells (Fig. 4C).

\section{Discussion}

The present data show that the toxic effects of lead occur at the level of the pituitary and gonadal components of the gonadotropic axis. Such effects of lead acetate on the hypothalamic-pituitary axis are dose-dependent. Exposure of rats to lead had a detrimental effect on growth of animals; the decrease in body weight could be due to toxic
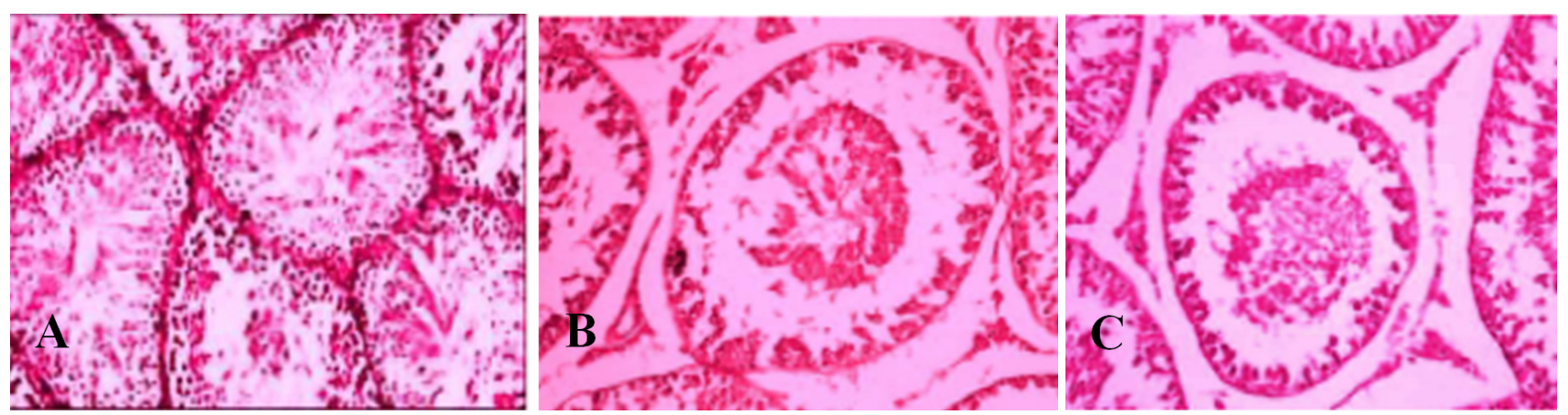

Fig. 3. Testicular histopathologic changes by HE staining (X200). Structure of seminiferous tubules was normal in control group; (B) Atrophification of seminiferous tubules, the number of leydig cells appeared to be lowered in the interstitium in $\mathrm{Pb}$-treated at $15 \mathrm{mg} / \mathrm{kg}$; (C) Histopathological changes are lesser in Pb-treated at $10 \mathrm{mg} / \mathrm{kg}$
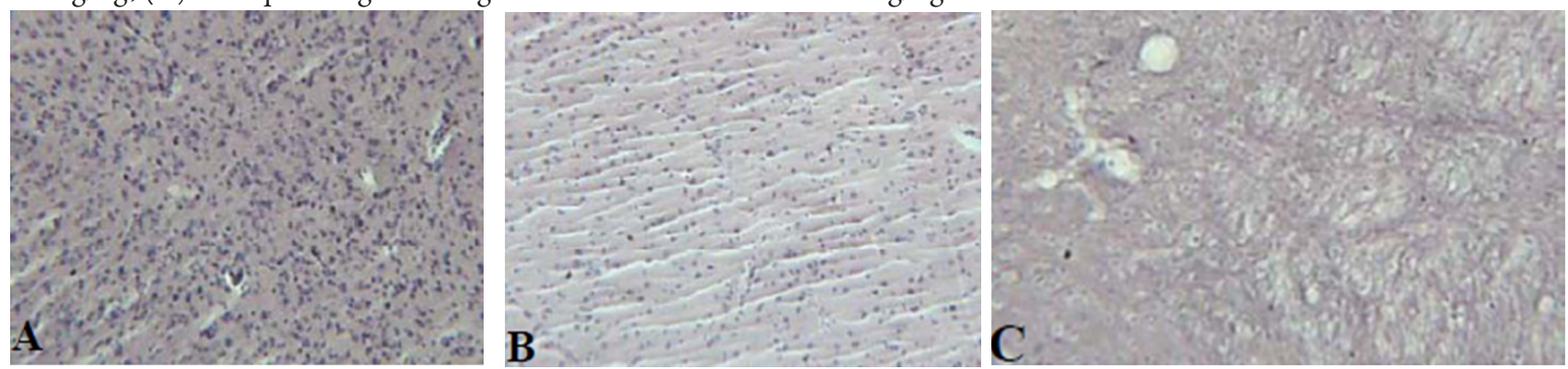

Fig. 4. Pituitary histopathologic changes by HE staining (X100). Pituitary of control; (B) pituitary of Pb-treated at $10 \mathrm{mg} / \mathrm{kg}$; (C) Pituitary $\mathrm{Pb}$-treated at $15 \mathrm{mg} / \mathrm{kg}$ 
4

effects of lead on cellular metabolism (Wapnir et al., 1977) and not due to underfed or undernourished conditions. It has been suggested that loss in body weight in general on heavy metal exposure can be attributed to the enhanced synthesis of glucose from noncarbohydrate sources, that is, metabolization of fat deposits (Tandon and Tewari, 1987). Alcoholism is associated with increase in metabolic rate and increased brown fat thermogenesis in rats and humans, which in turn, may be responsible for the decrease in growth of the animals (Ahmed, 1995). Further, lead is possibly acting together, resulting, in poor growth of animals. Although significant decrease in the weight of brain has been observed, the percentage decrease in weight of rats treated with lead was greater than that of the brain control, which could be the result of high vulnerability of brain cortex towards various toxic exposures of lead. Reduced weights of various brain areas, including cerebral cortex, cerebellum, and hippocampus, also have been reported by Lampert et al. (1967) during lead encephalopathy in suckling rats. Lorton and Anderson (1984) reported a number of alterations in lead-exposed cerebellum, including a decrease in molecular layer width, granular cell density and dendritic arborisation, after a decrease in total weight. The distribution of lead in the various regions of brain does not appear to be uniform. It has been reported that in rats there is a selective accumulation of lead in the hippocampus (Fjerdingstad et al., 1974). In our study it has been observed that lead levels in the brain increased significantly in treated rats as compared with the control. Kuhlmann et al. (1997), Flora and Seth (2000) have also reported differential accumulation lead levels in brain. Klein and Koch (1981) postulated that in lead-exposed animals, lead concentrates in cerebellum and cerebral cortex. An almost similar observation was given by Collins $e t$ al. (1982), rats increased significantly after lead treatment for 6 weeks. However, in cerebellum, lead has tendency to accumulate in white matter rather than cortical grey matter, either by transport to edema fluid formed in the cortex as result of vascular damage or by direct passage over the damaged in the white matter (Lindh et al., 1989). This, however, is possibly due to an effective blood-brain barrier, known to restrict the entry of heavy metals in brain, and many such examples in literature confirm our findings (Flora and Tandom, 1987; Pal et al., 1993). This is also supported by the observation that immature animals accumulated more lead in the brain because of the underdeveloped blood-brain barrier (Willes et al., 1977). Further, our results are in agreement with those of Flora and Tandom (1987), who reported significantly higher accumulation of lead in the whole brain of rats coexposed to lead and ethanol. Metal toxicity or lead toxicity affects the normal histological structure of the brain and causes disturbances in the normal functions performed by them. Clasen et al. (1974) reported cerebral edema, muscular changes, and focal cerebellar atrophy involving Purkinje's and granular cells and neural degeneration as a result of lead en- cephalopathy in rat brain. Lead damages the nerve cells and ganglia and alters the cell structure (Fantin et al., 1985). Histologically, in the present study, disorganization of cells in the successive layers of cerebral cortex was seen in the lead-treated group. Lead and its ions induced oxidative stress in cells by several distinct mechanisms. Because lead has a high affinity for sulfhydryl residues in proteins, it has been proposed that the toxicity of lead is the result of its ability to act as a nonspecific enzyme inhibitor. It also exerts its toxic effects by combining with oxygen and sulfur-containing bioligands. It has been advocated as a calcium mimic as well as it causes oxidative stress in cells, which is detrimental to a cell's survival (Lawton and Donaldson, 1991; Zelikoff et al., 1988). The oxygen radicals that are normally produced within the body are usually kept in check by complex multifactorial protective enzymes, which include catalase, superoxide dismutase and glutathione peroxidase, which can check the free radicals originating either in the mitochondria or in the cytoplasm. However, the brain is one organ that is, at first instance, susceptible to peroxidase damage (Julka et al., 1992). Lead can alter the cellular redox state by inhibiting the enzymes involved in antioxidant defense, that is catalase, glutathione peroxide, glutathione and superoxide dismutase, which function as blockers of free radical process (Dormandy, 1978). Most of these enzymes are metalloenzymes, w sulfhydryl groups which are essential for their activities, and the oxidation of these groups that are essential for their activities, and the oxidation of these groups by lead may result in partial or complete inhibition of antioxidant defense system. The reduction of antioxidant enzymes may result in alteration in membrane integrity, thereby increasing the susceptibility of the membrane to metal exposure (Floche and Zimmermannn, 1970). The decrease in catalase could be the result of in a decrease in substrate levels, $\mathrm{H}_{2} \mathrm{O}_{2}$ (Aebi, 1974), or a reduced synthesis of enzyme itself as result of higher intracellular concentration of lead/trace metal. Concerning the hormonal levels, our results showed a decrease in both plasma $\mathrm{LH}$ and testosterone in the animals exposed to lead for 20 days. Reproductive hormones play an important role in the regulation of spermatogenesis and sperm development. Our results well correlate with previous studies showing that in rat the effects of lead involve multiple action sites on male reproductive hormones although the most important part of these disorders probably occurs in the hypothalamic-pituitary axis (Ronis et al., 1996; Sokol et al., 1985). For example, depending on lead exposure levels and duration, signals within and between the rat's hypothalamus and pituitary appears to be disrupted by lead (Sokol et al., 2002). In a study of leadexposed rats hyper responsiveness to stimulation with gonadotropin releasing hormone $(\mathrm{GnRH})$ and luteinizing hormone (LH) was demonstrated (Sokol, 1987). In addition, McGregor (1990) reported a positive correlation between serum LH levels and duration of occupational lead exposure. Testosterone, the main male sex hormone, is 
produced and secreted by Leydig cells of testis in response to LH stimulation. Lead concentrations in the Semen at a mean of $2 \mu \mathrm{g} / \mathrm{dl}$ have been reported to be inversely correlated to serum testosterone among occupationally-exposed men (Alexander et al., 1997). The findings suggest the involvement of other hormonal and/or hormonal feedback pathways (s) than disruption of testosterone secretion in the reproductive hormonal axis by lead, such as a lack of reflex in response to plasma testosterone, direct inhibitory androgen in Leydig cells (Wiebe et al., 1983), or defects in LH regulation at the pituitary level (Sokol et al., 1985). Molecular mechanisms underlying histopathological examination have revealed disturbance degeneration in Leydig cells among rats, thereby suggesting Leydig cells as a target for lead intoxication (Mohsen Vigeh et al., 2011). Our histopathological examination of rats intraperitoneally administered lead acetate showed alteration in the testis with a marked degeneration and necrosis of germ cells lining seminiferous tubules, as well as interstitial odema and complete absence of germ cells. The histological changes in testis of lead administered rats are in agreement with those reported by Hachi et al. (2008). Furthermore, Garu et al. (2011) monitored the developmental effects on testes of male offspring of lead exposed Swiss mice during gestation and lactation. The results revealed that lead induced apparent damage and reduction in the number, changes in shape and size of developing seminiferous tubules. Oral exposure of lead acetate changed the arrangement and shape of spermatogonial cells and reduced the number of Sertoli cells (Garu et al., 2011). It also diminished the development of Leydig cells.

In conclusion, the results of our study demonstrate that daily intraperitoneal administration of lead acetate in rats during 20 days induced a significant fall in the secretion of LH and testosterone. Although we cannot exclude a direct toxicity of lead on the interstitial cells and the Sertoli cells, it seems that the major target of lead toxicity in the reproductive hypothalamic-pituitary axis via a reduction, in the LH secretion. Further studies are still required to explain the mechanism of lead toxicity and especially to clarify the role of hypothalamic-pituitary axis in testicular dysfunction.

\section{References}

Aebi H (1974). Catalase, 673 p. In: Bergmeyer HU (Ed.). Methods in enzymatic analysis, 2, New York, Academic Press.

Aebi H (1984). Catalase in vitro. Methods Enzymol 105:121126.

Ahmed FE (1995). Toxicological effects of ethanol on human health. Crit Rev Toxicol 25:347-367.

Alexander BH, Checkoway H, Faustman EM, Van Netten C, Muller CH, Ewers TG (1997). Contrasting associations of blood and semen lead concentrations with semen quality among lead smelters workers. Am J Ind Med 34:4694-4699.
Anttila A, Heikkilä P, Nykyri E (1995). Excess lung cancer among workers exposed to lead. Scan J Work Environ Health 21:460-469.

Apostoli P, Kiss P, Porru S, Bonde JP, Vanhoorne M (1998). Male reproductive toxicity of lead in animal and humans, Asclepios Study Group. Occup Environ 55:364-374.

Bancroft D, Stevens A, Tumer R (1996). Theory and practice of histological technique, $4^{\text {th }}$ ed., Churchill Living Stone. Edinburg London Melbourne, 47-67 p.

Cardona E, Lessler MA (1974). Time course of hematologic changes during chronic lead poisoning. Proceed Soc Esper Biol Med 145:668-668.

Chakraborty R, Das A, Cerveara ML de la Guardia M (1996). Determination of cadmium by electrothermal atomic absorption spectrometry after microwave-assisted digestion of animal tissues and sewage sludges. Fresenius J Ann Chem 335:43-47.

Clasen RA, Hartman JF, Coogan PS, Pandolfi S, Laing J, Becker RA (1974). Experimental acute lead encephalopathy in the juvenile rhesus monkey. Exp Health Perspect 7:175-185.

Collin MF, Hrdina PD, Whittle E, Singhal RL (1982). Lead in blood brain regions of rats chronically exposed to low doses of the metal. Toxicol App Pharmacol 65:314-332.

Der R, Fahim Z, Yousef M, Fahim M (1976). Environmental interaction of lead and cadmium on reproduction and metabolism of metal rats. Res Commun Chem Pathol Pharmacol 14:689.

Dormandy TL (1978). Free-radical oxidation and antioxidants. Lancet 1:647-650.

Fantin AMB, Franchini A, Ottaviani E, Benedetti L (1985). Effects of pollution on some freshwter species. II. Bioaccumulation and toxic effcts of experimental lead pollution on the ganglia in viviparous ater (Mollusca gastropoda). Basic Appl Histochem 29:377-387.

Fjerdingstad EJ, Danscher G, Fjerdingstad E (1974). Hippocampus: selective concentration of lead in normal rat brain. Brain Res 80:350-354.

Floche I, Zimmermannn R (1970). The role of GSH peroxidase in protecting the membrane of rat liver mitochondria. Biochim Biophys Acta 223:210-213.

Flora GJ, Seth PK (2000). Alteration in some membrane properties in rat brain following exposure to lead. Cytobios 103:103-109.

Flora SJS, Tandom SK (1987). Effect of combined exposure to lead and ethanol on some biochemical indices in the rat. Biochem Pharmacol 36:537-541.

Garu U, Sharma R, Barber I (2011). Effect of lead toxicity on developing testis of mice. International Journal of Pharmaceutical Sciences and research 2:2403-2407.

Gorbel F, Boujelbene M, Makni-Ayadi F, Guermazi F, Croute F, Soleilhavoup JP, El Feki A (2002). Impact of lead given in drinking water on the endocrine and exocrine sexuel activity in pubescent rats. Determination of an apoptic process. 
6 Compes Rendus Biologies 325:927-940.

Goyer RA (1990). Transplacental transport of lead. Environ. Health Prospect 91:89101-89105.

Goyer RA (1989). Mechanisms of lead and cadmium nephrotoxicity. Toxicology Letters 46:153-162.

Hachfi L, Trimèche M, Chekir A, Kerkeni A, Najjar MF, Sakyl R (2008). Effects of oral intoxication by lead acetate on pituitary-testicular axis in the pubertal rat. Italian Journal of Public Health 5:297-303.

Hertz-Picciotto I, Croft J (1993). Review of the relation between blood lead and blood pressure. Epidemiologic Reviews 15:352-73.

Hogstedt C, Hane M, Agrell A, Bodin L (1983). Neuropsychological test results and symptoms among workers with welldefined long-term exposure to lead. Br J Ind 40:99-105.

Julka D, Pal R, Gill KD (1992). Neurotoxicity of dichlorvos: effect on antioxidant system in the rat central nervous system. Exp Mol Pathol 56:144-152.

Klein AW, Koch TP (1981). Lead accumulation in brain, blood and liver after low dosing in neonatal rats. Arch Toxicol 47:257-262.

Krachler M, Radner H, Irgolic KJ (1996). Microwave digestion methods for the dermination of trace elements in brain and liver samples by inductively coupled plasma mass spectrometry. Fresenius J Anal Chem 355:120-128.

Lampert PW, Garro F Pentshew A (1967). Lead encephalopathy in suckling rats: an electron microscopic study, $207 \mathrm{p}$. In Klatzo I, Seitalberges F (ed.). Symposium on brain Edema, Springer, NV.

Lawton LJ, Donaldson WE (1991). Lead-induced tissue fatty alterations and lipid peroxidation. Biol trace elem res 28:8397.

Lindh U, Chondri NG Sourander P (1989). Distribution of lead in cerebellum of suckling rats following low and highg dose lead exposure. Acta neuropathol 79:149-153.

López-Carrillo L, Torres-Sánchez L, Garrido F, PapaquiHernández J, Palazuelos-Rendón E, López-Cervantes M (1996). Prevalence and determinants of lead intoxication in Mexican children of low socio-economic status. Environ Perspect 104:1208-1211.

Lorton D, Anderson WJ (1984). The effects of postnatal lead toxicity on the development of the cerebellum in rats. Neurochem toxicol terato 8:51-59.

McGregor AJ, Mason HJ (1990). Chronic occupational lead exposure and testicular endocrine function. Hum Exp Toxicol 9:371-376.

Mohsen Vigh, Derek R, Ping-Ch H (2011). How does lead induce male infertility? Iranian Journal of Reproductive Medecine 9(1):1-8.

Pal R, Nath R, Gill KD (1993). Influence of ethanol an cadmium accumulation and its impact on lipid peroxidation and membrane bound enzymes. Neurochem Int 23:451-458.

Piomelli S (1981). Chemical toxicity of red cells. Environ Health
Perspect 39:65-70.

Ronis MJ, Badger IM, Shema SJ, Roberson PK, Shaikh P (1996). Reproductive toxicity and growth effects in rats exposed to lead at different periods during development. Toxicol Appl Pharmacol 136:361-371.

Ronis MJ, Badger TM, Shema SJ, Roberson PK, Templer L, Ringer D, Thomas PE (1988). Endocrine mechanisms underlying the growth effects of developmental lead exposure in the rat. J Toxicol Environ Health 54:101-120.

Sandhir R, Julka D, Gill KD (1994). Lipoperoxidative damage on lead exposure in rat brain and its implications on membrane bound enzymes. Pharmacol Toxicol 74:66-71.

Schwartz J (1995). Lead, blood pressure, and cardiovascular disease in men. Environ Health Pespect 91:71-75.

Seppäläinen AM, Hernberg S, Vesanto R, Kock B (1983). Early neurotoxic effects of occupational lead exposure: A prospective study. Neurotoxycology 4:181-192.

Sokol RZ (1987). Hormonal effects of lead acetate in the male rat: mechanism of action. Biol Repro 37:1135-1138.

Sokol RZ, Madding CE, Swerdolff RS (1985). Lead toxicity and the hypothalamic-pituitary-testicular-axis. Biol Reprod 33:722-728.

Sokol RZ, Wang S, Stanczyk YJ, Gentzschein E, Chapin RE (2002). Long-term, low-dose lead exposure alters the gonadotropin-releasing hormone system in the male rat. Environ Health Perspect 110:871-874.

Stumpf WE, Sar M, Grant LD (1980). Autoradiographic locolalization of $(210) \mathrm{Pb}$ and its decay products in rat forebrain. Neurotoxicology 1:593.

Sugawara E, Nakamura K, Miyake T, Fukumura A, Seki Y (1991). Lipid peroxidation and concentration of glutathione in erythrocytes from workers expose to lead. British J industrial Med 48:239-242.

Tandon SK, Tewari PC (1987). Effect of coexposure to ethanol and cadmium in rats. Bull Environ Contam Toxicol 39:633 640.

Thoreux-Manlay A, Le Goascogne C, Segretain D, Jégou B, Pinon-Lataillade $G$ (1995). Lead affects steroidogenesis in rat Leydig cells in vivo and in vitro. Toxicology 103:53-62.

Wapnir RA, Exeni RS, Mc Viar M, Lifschitz E (1977). Experimental lead poisoning and intestinal transport of glucose, amino acids and sodium. Pediatr Res 11:153-157.

Wiebe JP, Salhanick AL, Myers KI (1983). On the mechanism of action of lead in the testis: in vitro suppression of FSH receptors, cyclic AMP and steroidogenesis. Life Sci 32:19972005.

Willes RF, Lok E, Truelove F, Sunderam A (1977). A retention and tissue distribution of ${ }^{210} \mathrm{~Pb}\left(\mathrm{NO}^{3}\right)^{2}$ administered orally to infant and adult monkeys. J Toxicol Environ Health 3:395-406.

Zelikoff JT, Li JH, Hartwig A, Wang XW, Costa M, Rossman TG (1988). Genetic toxicology of lead compounds. Carcinogenesis 9:1727-1732. 